\title{
Meteorological and hydrological drought from 1987 to 2017 in Doce River Basin, Southeastern Brazil
}

\section{Seca meteorológica e hidrológica de 1987 a 2017 na bacia hidrográfica do rio Doce, Sudeste do Brasil}

\author{
Elaisa Teixeira de Jesus ${ }^{1}$ (D), Jhones da Silva Amorim ${ }^{1}$ (D), Rubens Junqueira ${ }^{1}$ (D), Marcelo Ribeiro Viola ${ }^{1}$ (D), \\ \& Carlos Rogério de Mello ${ }^{1}$ (D) \\ ${ }^{1}$ Departamento de Recursos Hídricos e Saneamento, Universidade Federal de Lavras, Lavras, MG, Brasil. \\ E-mails: elaisafj@yahoo.com.br(ETJ),jhonesamorim@gmail.com (JSA),rubensjunqueira@live.com (RJ),marcelo.viola@ufla.br(MRV), \\ crmello@ufla.br (CRM)
}

Received: December 06, 2019 - Revised: March 13, 2020 - Accepted: April 14, 2020

\begin{abstract}
Meteorological drought is a natural hazard characterized as below-average precipitation from expected or normal that can affect various economic sectors, and lead to period with inadequate streamflow for established uses of the water (hydrological drought). We aimed to apply the Standardized Precipitation Index (SPI) and Standardized Streamflow Index (SSI) to identify the occurrence and the intensity of droughts in Doce River Basin (DRB), Southeastern Brazil. For this purpose, 71 rain gauge stations and one streamflow station were selected with 30-year monthly historical series (1987 to 2017). The SPI and SSI were calculated for the hydrological year (October-September) and the seasons (Spring, Summer, Fall, and Winter). SPI mapping was performed by geostatistical procedures. Pearson's coefficient was calculated to analyze the influence of meteorological on hydrological drought. The main meteorological drought events, observed in the hydrological years of 1994/95, 2000/01, and a recent and consecutive period of four hydrological years (2013-2017), were mainly influenced by events in spring and summer and, to a lesser extent, in fall. It was observed the influence of the meteorological drought on the hydrological drought on an annual and seasonal scale, except winter, where low precipitation does not influence in the streamflow.
\end{abstract}

Keywords: Extreme events; Precipitation regime; Standardized Precipitation Index; Standardized Streamflow Index; Water resources management.

\section{RESUMO}

A seca meteorológica é um fenômeno natural caracterizado por precipitações abaixo da média, com relação ao valor esperado ou normal, que podem afectar vários sectores econômicos e levar a um período com vazões inadequadas para usos estabelecidos (seca hidrológica). Foi aplicado o Índice de Precipitação Padronizado (SPI) e o Índice de Escoamento Padronizado (SSI) para identificar a ocorrência e a intensidade das secas na bacia hidrográfica do rio Doce (DRB), Sudeste do Brasil. Para isso, foram seleccionadas 71 estações pluviométricas e uma estação de vazão com séries históricas mensais de 30 anos (1987 a 2017). O SPI e o SSI foram calculados para o ano hidrológico (outubro-setembro) e para as estações do ano (primavera, verão, outono e inverno). O mapeamento do SPI foi realizado por procedimentos geoestatísticos. O coeficiente de correlação de Pearson foi calculado para analisar a influência da meteorologia na seca hidrológica. Os principais eventos meteorológicos de seca foram observados nos anos hidrológicos de 1994/95, 2000/01 e em um período recente e consecutivo de quatro anos hidrológicos (2013-2017), principalmente influenciados por eventos na primavera e verão e, em menor escala, no outono. Foi observada a influência da seca meteorológica sobre a hidrológica em escala anual e sazonal, exceto no inverno, em que a baixa pluviosidade não influenciou a vazão.

Palavras-chave: Eventos extremos; Regime pluviométrico; Índice de Precipitação Padronizado; Índice de Escoamento Padronizado; Gestão de recursos hídricos. 


\section{INTRODUCTION}

The World Meteorological Organization (2016) defines drought as a prolonged period in which total precipitation over a specific region is lower than the long-term average, causing a hydrological imbalance between the water demand and availability. Drought is a natural and complex phenomenon (Wilhite et al., 2007; Marengo et al., 2016), and negatively affects agriculture, hydropower generation, and other water uses in the watershed (Ding et al., 2011; Blauhut et al., 2015). Therefore, there has been important research focused on drought monitoring and forecasting (Brito et al., 2018; Marengo et al., 2016; Vicente-Serrano et al., 2012a)

There are different categories of the drought depending upon the perspective and the reference variable considered. Wilhite \& Glantz (1985) distinguish between four types of drought: meteorological, agricultural, hydrological and socio-economic. The meteorological drought is associated with the lack of precipitation due to the global behavior of the ocean-atmosphere system (Pedro-Monzonís et al., 2015). Agricultural drought occurs when the atmospheric demand for evapotranspiration is greater than the amount of plant-available water in the soil (Woli et al., 2012). The hydrological drought is related to the period with inadequate water flows for established uses of the water (Mishra \& Singh, 2010). The socio-economic drought is a consequence of the water scarcity and economic activity, including the environmental impacts (Pedro-Monzonís et al., 2015).

In recent years the drought events carried out a large number of environmental and socio-economic impacts. For example, a drop in gross primary production during the summer of 2003 in Europe, which led to a large release of carbon, was reported by Reichstein et al. (2007). According to Potter et al. (2011), the 2010 drought led to a reduction in net primary production in the Amazon rainforest, Brazil, by an average of $7 \%$ compared to 2008. In the semiarid region of Northeastern Brazil, the droughts that occurred in the 2011 and 2016 years affected a large area with significant impacts on the economic activities (Brito et al., 2018). Statistically significant impacts on hydropower usable capacity were found in Europe (-6.6\%) and Eastern North America (-6.1\%) during major drought years compared to long-term average for the 1981-2010 period (van Vliet et al., 2016).

Although it is difficult to prevent a meteorological drought occurrence, when its relationship with the hydrological drought is known, actions can be taken to mitigate the impact on the rivers (Barker et al., 2016). However, most of the drought studies carried out in Brazil are focused on meteorological drought, as Lima et al. (2019) and Gois et al. (2015).

Melo et al. (2016) evaluated the linkages between meteorological and hydrological droughts in the Paraná Basin, Southeastern Brazil, and identified a reduction from 20 to $50 \%$ of precipitation compared to the long-term average in the early 2000s and 2014. As a result, the reservoir system storage capacity decreased by $30 \%$ of the maximum storage capacity.

Southeastern Brazil has also been affected by droughts in the last decade. According to Cupolillo et al. (2008), the drought observed in 2005/06 caused great impacts on agriculture in the Doce River Basin. Besides, the Brazilian Ministry of Integration estimates that from 2012 to 2014 the most severe droughts of the last decades occurred in Southeastern Brazil with losses of approximately 6 billion dollars in the agricultural sector (Marengo et al., 2016).

Lima et al. (2019) developed an annual drought classification system for Doce River Basin, divided it into nine sub-basins, based on four indices, including the Standardized Precipitation Index (SPI). The most critical drought events were observed in the second half of the time series (from 2000 to 2015), where the events were more intense and longer-lasting. The indices were calculated annually, however, a seasonal scale might improve the understanding of drought events in the Doce River Basin. Besides, seasonal SPI is useful for agricultural production planning, especially in the crop growth phase (World Meteorological Organization, 2012).

Several drought indexes have been created and used to characterize the severity of the events (Bayat et al., 2015; Dahal et al., 2016; Ionita et al., 2016). The SPI is widely disseminated and easy to use (Okpara et al., 2017). It is considered as the standard index for the monitoring of drought events (World Meteorological Organization, 2012) and has been used in different regions of Brazil for drought monitoring (Santos et al., 2017; Brito et al., 2018; Sobral et al., 2018). The Standardized Streamflow Index (SSI) is a hydrological drought index that allows the researcher to make a temporal and spatial comparison between flow data on different flow regimes and characteristics (Vicente-Serrano et al., 2012a, 2012b).

Therefore, we aimed to spatially analyze the SPI behavior in two timescales (seasonal and annual) in Doce River Basin in the last 30 years (October 1987 to September 2017) and to verify the interaction between meteorological and hydrological droughts through the SSI.

\section{MATERIALS AND METHODS}

\section{Study area}

The Doce River Basin (DRB) is located in southeastern Brazil, between the parallels $17^{\circ} 45^{\prime}$ and $21^{\circ} 15^{\prime} \mathrm{S}$ and the meridians $39^{\circ} 30^{\prime}$ and $43^{\circ} 45^{\prime}$ W. It drains an area of $86,710 \mathrm{~km}^{2}$ in the states of Minas Gerais (MG) and Espírito Santo (ES). The major part of the basin is located in MG $(86 \%)$ and it covers 229 municipalities entirely or partially (Coelho, 2007; Comitê da Bacia Hidrográfica do Rio Doce, 2010). The location of DRB and the 30-m ASTER (United States Geological Survey, USGS) Digital Elevation Model, are presented in Figure 1. The altitude in the basin varies from $2,635 \mathrm{~m}$ at the headwater to $0 \mathrm{~m}$ at the mouth, with an average of $560 \mathrm{~m}$.

The Köppen climate-type classification in the basin can be described as "Cwb", temperate, with rainy and mild summers; "Cwa", sub-tropical, with rainy and hot summers; and "Aw", tropical, with hot and rainy summers (Comitê da Bacia Hidrográfica do Rio Doce, 2010).

DRB is influenced by the Tropical Atlantic (MTA), Polar Atlantic (MPA) and Continental Equatorial (MEC) air masses, characterized by the western wind flows. MEC operates in the spring and summer causing the highest temperatures. Also, in the lower course of the Doce River the temperature is high due to the effect of the maritime conditions; on the other hand, the temperature is milder in the headwater region (Cupolillo et al., 2008). 
According to the Brazilian Ministry of the Environment (Brasil, 2017), the predominant biome in the basin is the Atlantic Forest, corresponding to $98 \%$ of its area, the rest of the area is occupied by the Cerrado biome (Brazilian Savanna).

The total annual average precipitation in the DRB is approximately 1,182 $\mathrm{mm}$. In the hydrological year, spring and summer, there is a region in the extreme southwestern basin with the highest precipitation amount (Figure 2). As reported by Cupolillo et al. (2008), this occurs because of the orographic effect in this basin.

It can be observed that the highest depth of annual precipitation is concentrated in the summer season (Figure 2), whose average precipitation represents $47.7 \%(564 \mathrm{~mm})$ of the total in the hydrological year. In the spring and fall seasons, large areas of the DRB present precipitation values between 125 and $375 \mathrm{~mm}$ and together correspond to $48.7 \%$ of annual precipitation. Another relevant aspect is that during the winter the mean precipitation in DRB is lower than $45 \mathrm{~mm}$, representing only $3.6 \%$ of the annual total.

\section{SPI and SSI calculation and mapping}

To calculate the SPI and SSI, respectively, monthly historical series from 71 rain-gauges and one streamflow station were obtained, whose spatial distribution is presented in Figure 1, from the Hydrological Information System (HidroWeb) of the Brazilian National Water Agency (ANA) website, covering a period of 30 years (1987 - 2017). Only series with a maximum of $10 \%$ missing data were selected, as recommended by the WMO (World Meteorological Organization, 2012). The periods with gaps were discarded in the SPI and SSI calculation since no filling procedure was performed.

The first step in the SPI calculation is to fit a probability distribution function to the frequency occurrence of the precipitation values. For this purpose, Gamma 2P was fitted (McKee et al., 1993) and the estimated " $z$ " value from the inverse of the standard normal distribution corresponds to the SPI. The KolmogorovSmirnov test was performed with a statistical significance

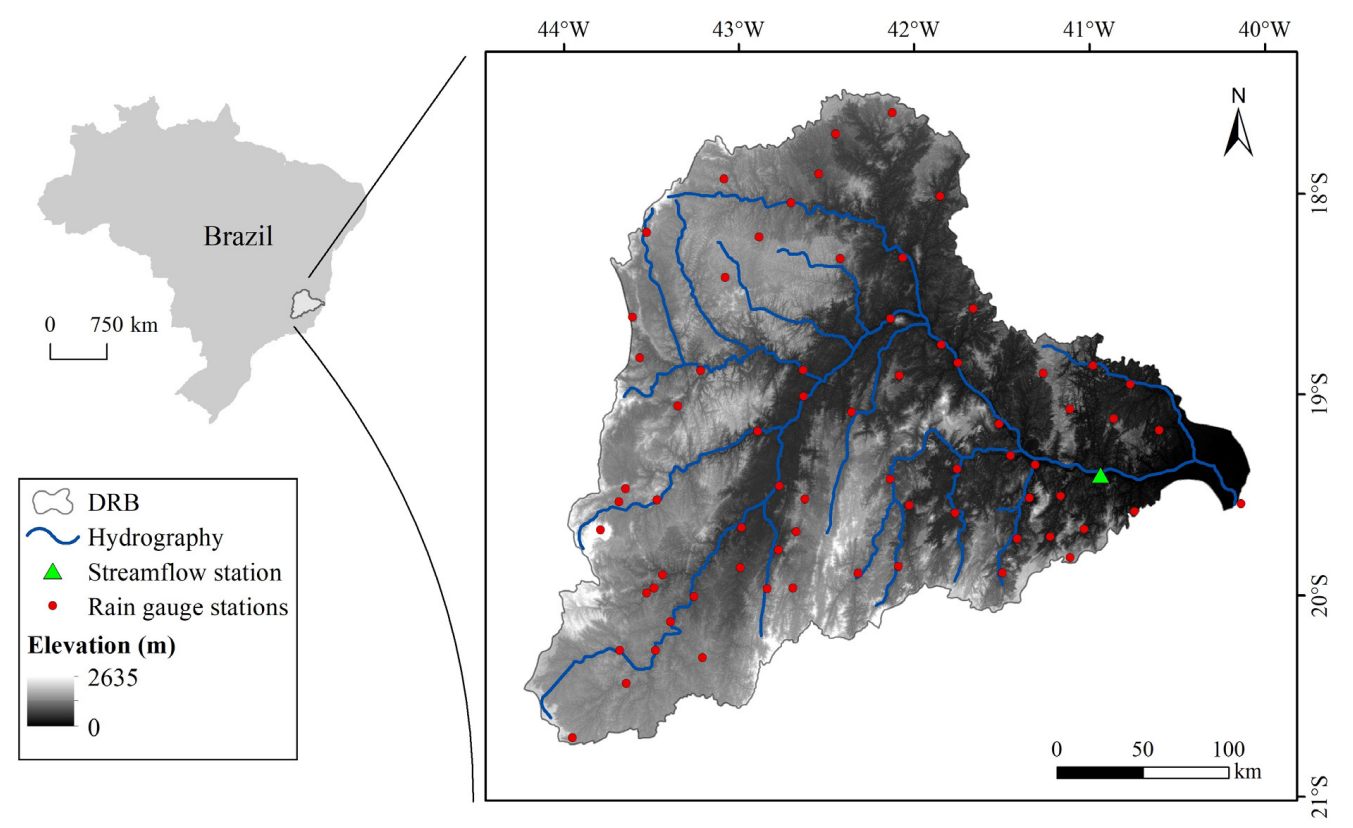

Figure 1. Location of DRB, DEM, rain gauge and streamflow stations, and hydrography.
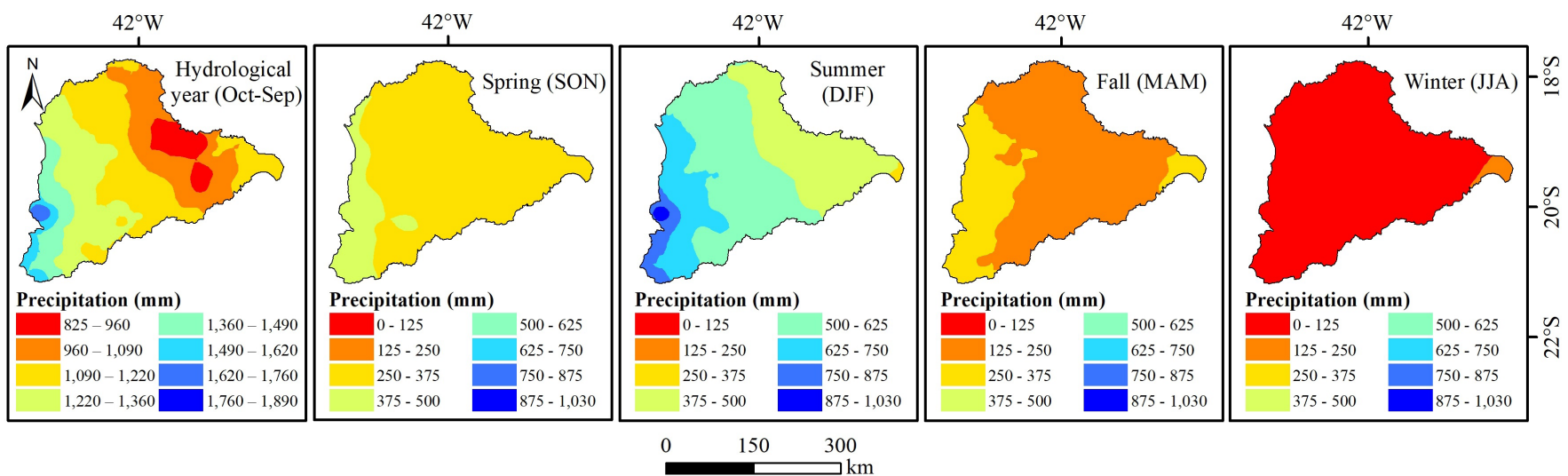

Figure 2. Total precipitation in DRB for the hydrological year and seasons from 1987 to 2017. 
of $5 \%\left(\Delta \mathrm{F}_{\text {Critical }(30 ; 0.05)}=0.242\right)$ to verify the suitability of the Gamma $2 \mathrm{P}$. The determination of SSI is similar to SPI, however, the input data is the streamflow (Vicente-Serrano et al. 2012b), where the Colatina streamflow station (Figure 1) was used, which has a drainage area of $76,400 \mathrm{~km}^{2}$.

SPI and SSI were calculated for each hydrological year (12 months, from October to September) and season of the corresponding year (3 months): Spring (September to November), Summer (December to February), Fall (March to May) and Winter (June to August). The streamflow series of 2014/15 was removed from SSI analyses due to missing data.

SPI and SSI values were analyzed and the drought severity classification was performed according to the methodology presented by McKee et al. (1993) and improved by WMO (World Meteorological Organization, 2012). The classification is shown in Table 1.

For Yevjevich (1967), in addition to intensity, drought involves other factors, such as duration and the affected area. Its duration was measured according to the beginning and end, and the affected area, based on maps of the SPI.

Spatial interpolation of the SPI values was performed by kriging, using the exponential semi-variogram model fitted by the Weighted Minimum Squared method (WMS). The performance of the kriging was analyzed based on the cross-validation technique, which estimates the SPI value for a given sampled location and compares this value to the observed one (McBratney \& Webster, 1986). From this dataset, the Mean Standardized Error (MSE), Root Mean Square Error (RMSE) and Average Standard Error (ASE) were calculated, respectively, by Equations 1, 2 and 3.

$$
\begin{aligned}
& \text { MSE }=\frac{1}{N} \sum_{i=1}^{N}\left(\frac{z^{*}\left(x_{i}\right)-z\left(x_{i}\right)}{\sigma\left(x_{i}\right)}\right) \\
& \text { RMSE }=\sqrt{\frac{1}{N}\left\{\sum_{i=1}^{N}\left(\frac{z^{*}\left(x_{i}\right)-z\left(x_{i}\right)}{\sigma\left(x_{i}\right)}\right)\right\}^{2}} \\
& \text { ASE }=\sqrt{\frac{\sum_{i=1}^{N} \sigma\left(x_{i}\right)}{N}}
\end{aligned}
$$

where $N$ represents the number of cross-validation data; $z\left(x_{i}\right)$ is the value observed at point $i ; z^{*}\left(x_{i}\right)$ is the estimated value for point $i$; and $\sigma\left(x_{i}\right)$ is the kriging standard deviation at point $i$.

The geostatistical model was considered accurate if the RSM is close to 0, the RMSE close to 1, and the ASE as small as possible according to the criteria presented by Kumar et al. (2007).

Table 1. Classification of SPI and SSI values.

\begin{tabular}{cc}
\hline SPI and SSI values & Classification \\
\hline$\geq 2.00$ & Extremely wet (EW) \\
1.50 to 1.99 & Very wet (VW) \\
1.00 to 1.49 & Moderately wet (MW) \\
0.99 to -0.99 & Near normal (NN) \\
-1.00 to -1.49 & Moderately dry (MD) \\
-1.50 to -1.99 & Severely dry (SD) \\
$\leq-2.00$ & Extremely dry (ED) \\
\hline
\end{tabular}

Source: Adapted from WMO (World Meteorological Organization, 2012).
The Spatial Dependency Degree (SDD) was calculated to verify the degree of spatial dependency present in the data in which SDD below 25\% means a "weak" degree of spatial dependency; between $25 \%$ and $75 \%$, "moderate"; and above $75 \%$, "strong" (Cambardella et al., 1994).

The SPI was mapped for the hydrological year scale between 1987 and 2017. Afterward, the six driest years were selected for a detailed analysis on the seasonal scale.

Pearson's coefficient with a statistical significance of $5 \%$ $(\alpha=0.05)$ was used to analyze the influence of meteorological drought on hydrological drought on an annual and seasonal scale. The coefficient was calculated between SPI average to DRB, obtained by ordinary kriging, and SSI to Colatina streamflow station.

\section{RESULTS AND DISCUSSION}

The Kolmogorov-Smirnov test confirmed the suitability of the Gamma 2P distribution for the precipitation and streamflow historical series. Table 2 presents the average results of the geostatistical analyses of SPI in DRB. Moderate and strong SDD were obtained in most of the events analyzed for the hydrological years and seasons. The results of MSE, RMSE, and ASE were satisfactory (MSE showed values near 0, RMSE values near 1 and ASE values reduced concerning totals), indicating goodness of fit for the exponential semi-variogram model. In a study carried out in Tocantins state, Gois et al. (2015) stated that the use of the exponential model to interpolate SPI resulted in good and detailed maps, which contributed to identifying drought events in this state.

The SPI values are presented in Figure 3 for the hydrological year, which allowed to identify the occurrence of severe droughts in the years of 1994/95, 2000/01 and the period from 2013 to 2017.

The SPI on a seasonal scale for the six driest years identified during the study period are shown in Figure 4. Winter showed no significant influence on the SPI results of the respective hydrological year. It can be explained by the low precipitation amount in this season (Figure 2). For instance, although the hydrological year of $1988 / 89$ presented winter from very wet to extremely wet in entire the basin, it was classified as near normal in annual scale.

The drought of the 1994/95 hydrological year occurred mainly in the eastern and northwestern basin, which includes the Units of Planning and Management of Water Resources (UPGRHs) of the Caratinga river and the Manhuaçu river in Minas Gerais and Espírito Santo territory. The drought was influenced by the low precipitation during spring and, mainly, during the summer (rainy period properly said).

The drought that occurred in Brazil in the 2000/01 hydrological year is singular because it is related to the national energy crisis, which was known as "blackout" of the Brazilian National Energy System. Marengo \& Alves (2015) state that, among the factors

Table 2. Geostatistical analyzes results for SPI in DRB.

\begin{tabular}{ccccc}
\hline Time scale & SDD (\%) & MSE & RMSE & ASE \\
\hline Hydrological year & 78.6 & -0.003 & 1.05 & -0.14 \\
Spring & 83.0 & -0.006 & 1.07 & -0.58 \\
Summer & 67.8 & -0.006 & 1.01 & -0.19 \\
Fall & 76.4 & -0.014 & 1.03 & -1.05 \\
Winter & 88.6 & -0.008 & 1.10 & -0.69 \\
\hline
\end{tabular}



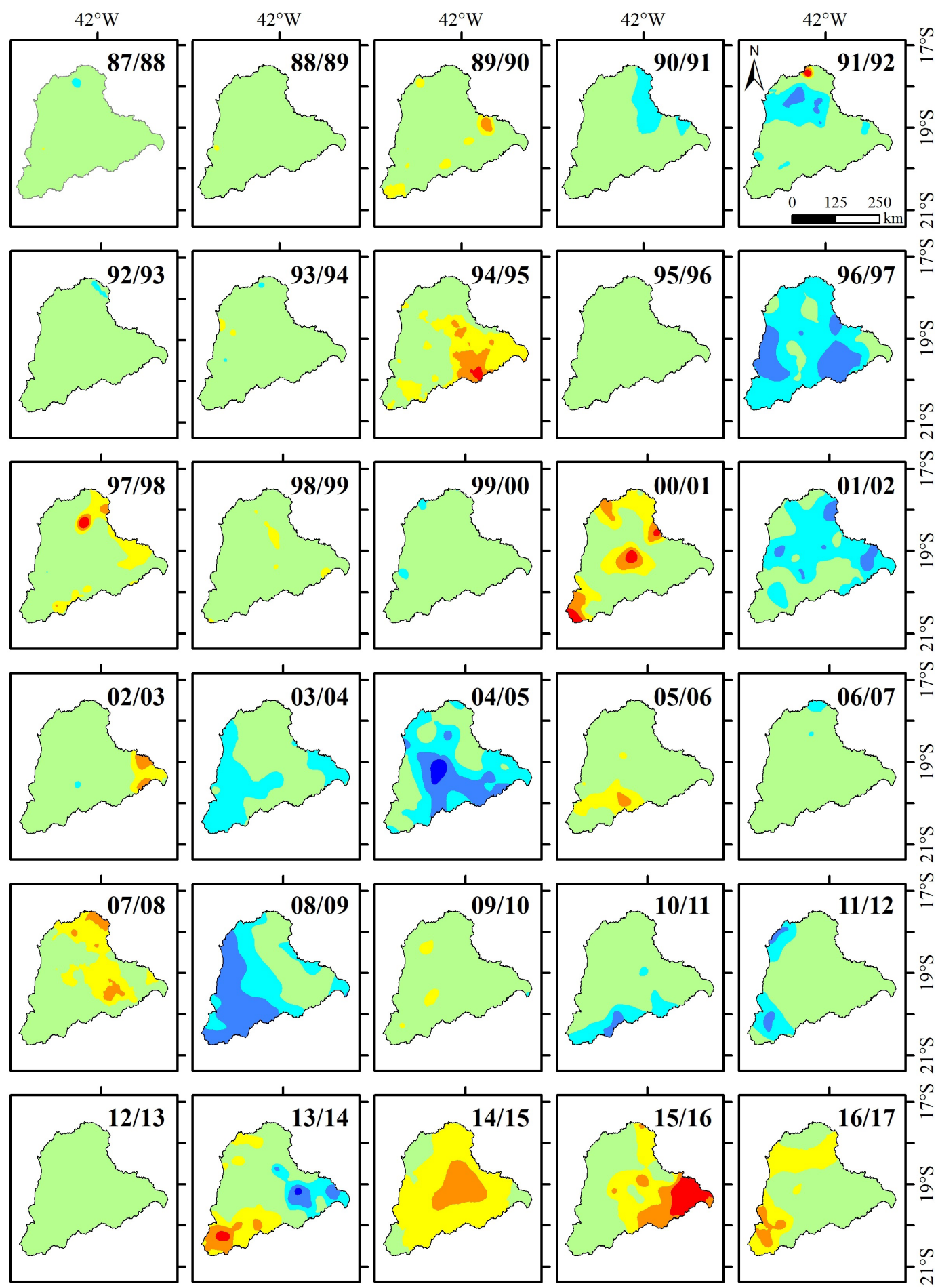

ED

SD

MD

$\mathrm{NN}$

MW

VW

EW

Figure 3. Maps of Standardized Precipitation Index (SPI) for the hydrological year in DRB from 1987 to 2017.

responsible for the "blackout" was the hydrological drought, caused by the meteorological drought, leading to low levels of the hydroelectric power plant reservoirs. According to Marengo (2008), the drought in 2000/01 can be explained by the ENSO phenomenon, the sea surface temperature variability of the South Atlantic Ocean, and the interannual climate variability.

Moreover, the hydrological drought of 2000/01 can be explained due to the low amount of precipitation in the summer, as the SPI classification for the other seasons was near to the normal. Another relevant aspect presented by Vicente-Serrano et al. (2017) is that because of the strong influence of temperature on droughts, the effects of this drought are more severe in the summer.

In the last four years evaluated (2013 to 2017), areas with severely dry SPI occurred in DRB, characterizing a long period of drought. Nobre et al. (2016) reported that this period is considered the most severe drought in southeastern Brazil since the 1950s. 

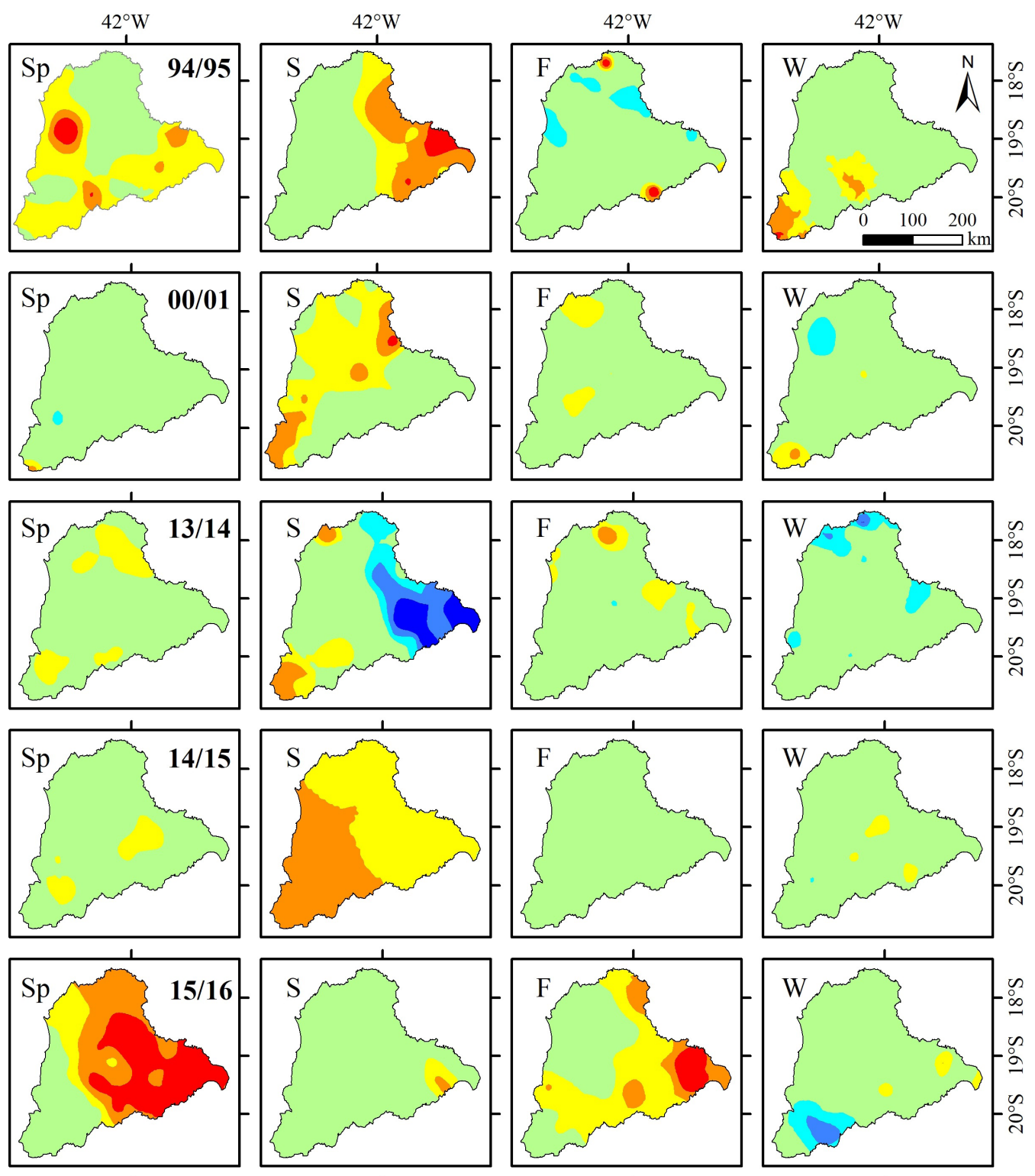

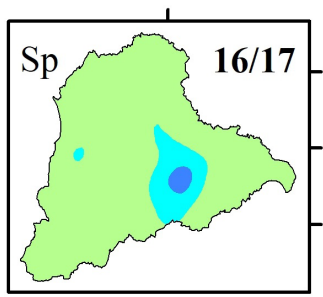

ED

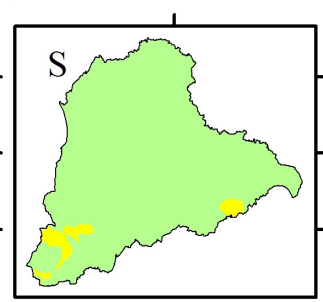

MD

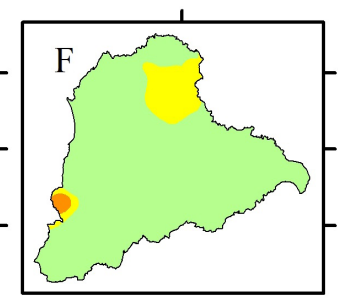

MW

VW

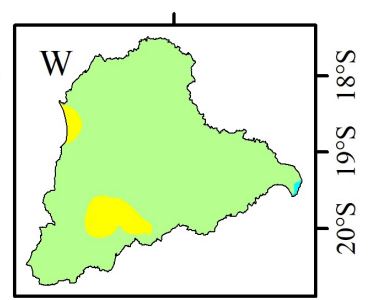

EW

Figure 4. Maps of Standardized Precipitation Index (SPI) for Spring (Sp), Summer (S), Fall (F), and Winter (W) in DRB from 1987 to 2017.

In January 2015 the storage capacity of the Cantareira reservoir system was only $5 \%$ of its total capacity and compromised the water supply of the approximately 9 million people in the metropolitan region of São Paulo.

During the hydrological year of 2013/14, the occurrence of the drought was detected mainly in the southwestern basin (Figure 3). However, areas with wet and normal SPI were also identified. This finding shows a high SPI spatial variability in the basin and points to the need of using indices associated with the streamflow, aiming to a better understanding of the relationship between meteorological and hydrological droughts, as a study performed by Melo et al. (2016) for the Paraná state.

In 2014/15 year, the most extensive drought occurred in DRB, reaching $83.5 \%$ of its area (Figure 3 ). There were exceptions of three small areas in the east, southwest and northwest regions, with normal SPI. It is observed that the drought of 2014/15 was strongly influenced by the low precipitation in spring and summer, since in the other seasons, in general, the SPI classification was 
near normal. According to IGAM (Instituto Mineiro de Gestão das Águas, 2015), in January 2015 there was a strong mass of dry and hot air in DRB, which caused an increase in temperature and reduction in precipitation.

In 2015/16, droughts occurred mainly in the eastern and central regions of the basin. Compared to the previous year (2014/15), although the drought a lesser spatial there was an extensive area in the east with an SPI classified as extremely dry. According to the DBR Committee (Comitê da Bacia Hidrográfica do Rio Doce, 2017), the period from March 2014 to May 2016 was considered as one of the most severe drought periods, so that the year 2015/16 was one of the driest in several locations in Minas Gerais state.

For the last hydrological year evaluated (2016/17), although the spatial coverage of drought areas has been limited compared to the previous three years, the climate event extended over the southwestern region, which has the highest average precipitation

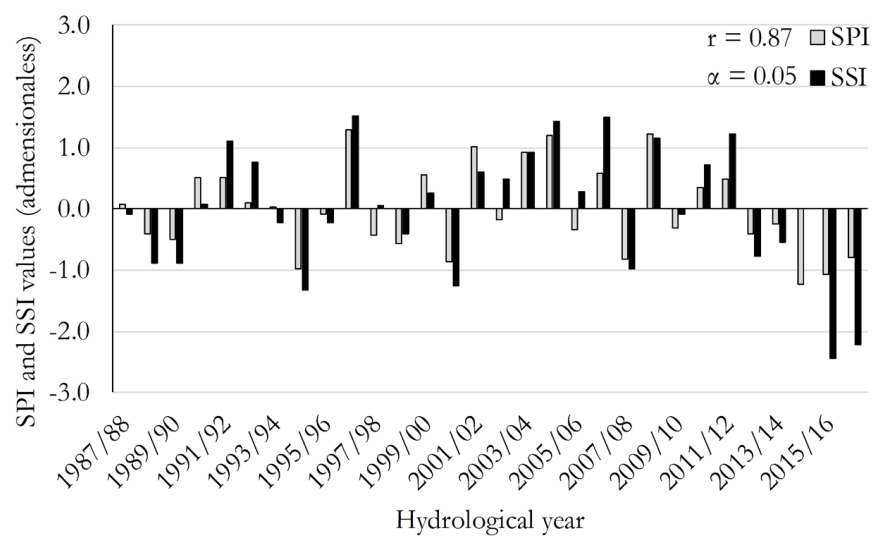

Figure 5. Result of SPI average in DRB and SSI in Colatina streamflow station, both for the hydrological year.
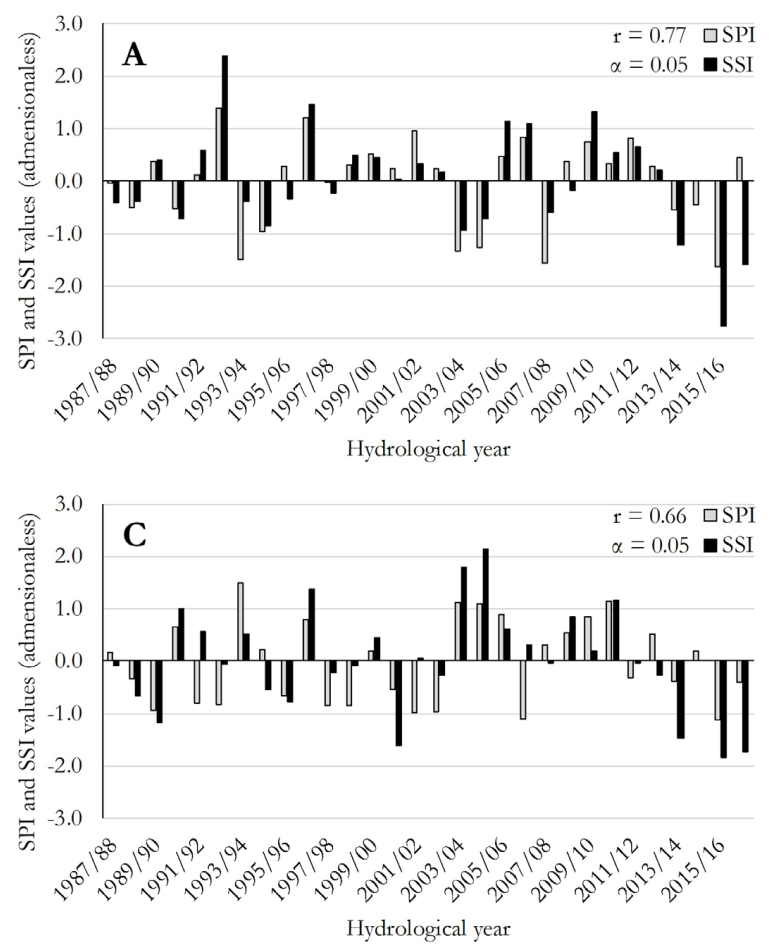

in DRB (Figure 2). In this way, the occurrence is evidenced by important meteorological drought in the last four hydrological years evaluated (2013/17).

The annual SSI and SPI average results for DRB from 1987 to 2017 are shown in Figure 5. The main hydrological drought events were observed in 1994/95, 2000/01, 2015/16 and 2016/17, of which the last two years were the most extreme in the analyzed period. Although the meteorological drought occurred in 2016/17 not presented high intensity and extent the SSI was classified as extremely dry. It may be explained by low groundwater recharge resulting from meteorological drought faced in the DRB in previous years (Figure 3).

It was possible to identify the impact of the meteorological drought on the Doce River streamflow regime through Pearson's coefficient $(r=0.87)$ between SPI and SSI. In addition, the years identified as dry by SPI have also been identified with the SSI (Figure 5) that note the SSI as useful to hydrological drought study in DRB. Similar results were observed by Marengo et al. (2011) on the Amazon basin, by Melo et al. (2016) on the Paraná river basin and Medeiros et al. (2019), and Marengo et al. (2013) to Northeastern Brazil, where meteorological drought affected streamflow and reservoir storage.

The drought experienced by DRB in 2015/16 and 2016/17 reflected in the levels of Doce River. The discharge of the Colatina streamflow station by January 2017 was $408 \mathrm{~m}^{3} \cdot \mathrm{s}^{-1}$, which is $74.8 \%$ below the long term monthly mean of $1620.27 \mathrm{~m}^{3} \cdot \mathrm{s}^{-1}$. This event also affected other Brazilian regions. As reported by Marengo et al. (2018), the meteorological drought in 2015/16 over the San Francisco River Basin, Southeastern Brazil, impacted the water available for vegetation and it affected the natural discharge entering the Três Marias reservoir.

The seasonal SSI and SPI average results for DRB from 1987 to 2017 are shown in Figure 6. The largest correlations occurred during seasons that concentrate most
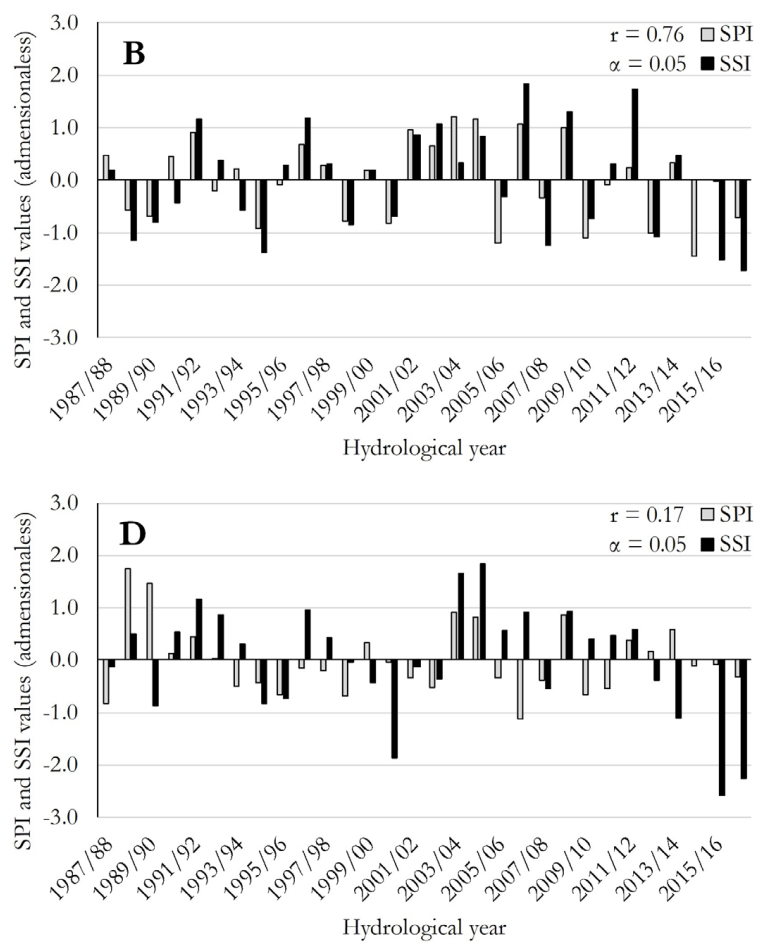

Figure 6. Results of SPI average in DRB and SSI in Colatina streamflow station for Spring (A), Summer (B), Fall (C), and Winter (D). 
of the annual precipitation (Figure 2), spring, summer, and fall $(r=0.77,0.76$, and 0.66 , respectively). The rainfall-runoff process can explain the highest correlation on these seasons.

The lower precipitation in winter (Figure 2) compared to other seasons entails that streamflow is influenced by groundwater recharge supplied at previous seasons, resulting in a low correlation between SPI and SSI in this season $(r=0.17)$. An example occurred in the years 2015/16 and 2016/17, where, although the winter SPI was classified "near normal", the SSI was classified as "extremely dry".

Although the lack of precipitation is the main cause of drought (Zarch et al., 2015), other factors such as temperature, strong winds, and low temperatures can aggravate these events, affecting soil moisture and the streamflows in the rivers (Wilhite, 2016). According to the National Centers for Environmental Information (2020), the ten warmest years between 1880 and 2019 occurred since 2005, which indicates that there is a clear increase in the average global temperature and, consequently, greater evapotranspiration. This new pattern of the climate has led to more frequent severe droughts in tropical and subtropical regions.

Therefore, indices that consider temperature or evapotranspiration, like the Standardized Precipitation-Evapotranspiration Index (SPEI) and Palmer Drought Severity Index (PDSI), may be a good alternative for drought studies. Pereira et al. (2018) observed through SPI and SPEI that there was an intensification of drought in the state of São Paulo caused by the increase in evapotranspiration, affecting agricultural production. A similar result was found by Zarch et al. (2015), who analyzed the drought between 1960 and 2009 and observed that from 1998, with the increase in temperature, the SPI revealed drought events in different climatic regions of the world.

\section{CONCLUSIONS}

The SPI maps made it possible to identify the hydrological years characterized as dry in DRB from 1987 to 2017. The hydrological years with the most severe meteorological droughts were 1994/95, 2000/01, and the last four years analyzed (2013/17).

The SPI analysis for the four seasons of the year proved to be fundamental for the complete understanding of precipitation in the hydrological year. It was verified that summer is the season most important for the definition of the SPI magnitude of a given hydrological year.

The hydrological drought was observed in the years 1994/95, 2000/01, 2015/16, and 2016/17, where the influence of the meteorological drought on these values can be observed, confirmed by Pearson's coefficient, which was $r=0.87$ for the annual SPI and SSI. Pearson's correlation coefficient showed that the rainy seasons had a greater influence on SSI in DRB due to groundwater recharge occurring in this period. Thus, the SPI of spring and summer showed a greater correlation with SSI, in contrast to what occurs in winter.

\section{REFERENCES}

Barker, L. J., Hannaford, J., Chiverton, A., \& Svensson, C. (2016). From meteorological to hydrological drought using standardised indicators. Hydrology and Earth System Sciences, 20(6), 2483-2505. http://dx.doi.org/10.5194/hess-20-2483-2016.

Bayat, B., Nasseri, M., \& Zahraie, B. (2015). Identification of long-term annual pattern of meteorological drought based on spatiotemporal methods: evaluation of different geostatistical approaches. Natural Hazards, 76(1), 515-541. http://dx.doi. org/10.1007/s11069-014-1499-3.

Blauhut, V., Gudmundsson, L., \& Stahl, K. (2015). Towards pan-European drought risk maps: quantifying the link between drought indices and reported drought impacts. Environmental Research Letters, 10(1), 014008. http://dx.doi.org/10.1088/17489326/10/1/014008.

Brasil. Ministério do Meio Ambiente - MMA. (2017). Download de dados geográficos. Brasília: MMA. Retrieved in 2018, November 15, from http://mapas.mma.gov.br/i3geo/datadownload.htm

Brito, S. S. B., Cunha, A. P. M., Cunningham, C. C., Alvalá, R. C., Marengo, J. A., \& Carvalho, M. A. (2018). Frequency, duration and severity of drought in the Semiarid Northeast Brazil region. International Journal of Climatology, 38(2), 517-529. http://dx.doi. org/10.1002/joc.5225.

Cambardella, C. A., Moorman, T. B., Parkin, T. B., Karlen, D. L., Novak, J. M., Turco, R. F., \& Konopka, A. E. (1994). Field-scale variability of soil properties in central Iowa soils. Soil Science Society of America Journal, 58(5), 1501-1511. http://dx.doi.org/10.2136/ sssaj1994.03615995005800050033x.

Coelho, A. L. N. (2007). Modelagem hidrológica da bacia do Rio Doce (MG/ES) com base em imagens srtm (shuttle radar topography mission). Caminhos de Geografia, 8(22), 116-131.

Comitê da Bacia Hidrográfica do Rio Doce - CBH-DOCE. (2010). Plano Integrado de Recursos Hídricos da Bacia Hidrográfica do Rio Doce e Planos de Ações para as Unidades de Planejamento e Gestão de Recursos Hídricos no Âmbito da Bacia do Rio Doce: Relatório final. Consórcio ECOPLAN - LUME. Retrivied in 2018, November 15, from http://www.cbhdoce.org.br/wp-content/uploads/2014/10/ PIRH_Doce_Volume_I.pdf

Comitê da Bacia Hidrográfica do Rio Doce - CBH-DOCE. (2017). Municípios da bacia hidrográfica do Rio Doce vivenciam efeitos do período de estiagem. Retrieved in 2018, November 15, from http://www. cbhdoce.org.br/geral/municipios-da-bacia-hidrografica-do-riodoce-vivenciam-efeitos-do-periodo-de-estiagem

Cupolillo, F., Abreu, M. L., \& Vianello, R. L. (2008). Climatologia da Bacia do Rio Doce e sua relação com a topografia local. Revista Geografias, 4(1), 45-60.

Dahal, P., Shrestha, N. S., Shrestha, M. L., Krakauer, N. Y., Panthi, J., Pradhanang, S. M., Jha, A., \& Lakhankar, T. (2016). Drought risk assessment in central Nepal: temporal and spatial analysis. Natural Hazards, 80(3), 1913-1932. http://dx.doi.org/10.1007/ s11069-015-2055-5. 
Ding, Y., Hayes, M. J., \& Widhalm, M. (2011). Measuring economic impacts of drought: a review and discussion. Disaster Prevention and Management: An International Journal, 20(4), 434-446.

Gois, G., Delgado, R. C., \& Oliveira Júnior, J. F. (2015). Modelos teóricos transitivos aplicados na interpolação espacial do Standardized Precipitation Index (SPI) para os episódios de El Niño forte no Estado do Tocantins, Brasil. Irriga, 20(2), 371-387. http://dx.doi. org/10.15809/irriga.2015v20n2p371.

Instituto Mineiro de Gestão das Águas - IGAM. (2015). Relatório hidrometeorológicos: período chuvoso 2014/2015. Belo Horizonte: IGAM. Retrieved in 2018, November 15, from https:/ / docplayer. com.br/25524011-1-relatorio-hidrometeorologico-periodochuvoso-2014-2015.html

Ionita, M., Scholz, P., \& Chelcea, S. (2016). Assessment of droughts in Romania using the Standardized Precipitation Index. Natural Hazards, 81(3), 1483-1498. http://dx.doi.org/10.1007/ s11069-015-2141-8.

Kumar, A., Maroju, S., \& Bhat, A. (2007). Application of ArcGIS geostatistical analyst for interpolating environmental data from observations. Environment and Progress, 26(3), 220-225. http:// dx.doi.org/10.1002/ep.10223.

Lima, R. P., Silva, D. D. D., Moreira, M. C., Passos, J. B. M. C., Coelho, C. D., \& Elesbon, A. A. A. (2019). Development of an annual drought classification system based on drought severity indexes. Anais da Academia Brasileira de Ciências, 91(1), e20180188. PMid:30994762. http://dx.doi.org/10.1590/0001-3765201920180188.

Marengo, J. A. (2008). Água e mudanças climáticas. Estudos Avançados, 22(63), 83-96. http://dx.doi.org/10.1590/S010340142008000200006.

Marengo, J. A., \& Alves, L. M. (2015). Crise hídrica em São Paulo em 2014: seca e desmatamento. GEOUSP Espaço e Tempo (Online), 19(3), 485-494. http://dx.doi.org/10.11606/issn.2179-0892. geousp.2015.100879.

Marengo, J. A., Alves, L. M., Alvala, R., Cunha, A. P., Brito, S., \& Moraes, O. L. (2018). Climatic characteristics of the 2010-2016 drought in the semiarid Northeast Brazil region. Anais da Academia Brasileira de Ciências, 90(2, Suppl.1), 1973-1985. PMid:28813107. http://dx.doi.org/10.1590/0001-3765201720170206.

Marengo, J. A., Alves, L. M., Soares, W. R., Rodriguez, D. A., Camargo, H., Riveros, M. P., \& Pabló, A. D. (2013). Two contrasting severe seasonal extremes in tropical South America in 2012: flood in Amazonia and drought in northeast Brazil. Journal of Climate, 26(22), 9137-9154. http://dx.doi.org/10.1175/JCLI-D-12-00642.1.

Marengo, J. A., Cunha, A. P., \& Alves, L. M. (2016). A seca de 2012-15 no semiárido do Nordeste do Brasil no contexto histórico. Revista Climanálise, 3, 49-54.
Marengo, J. A., Tomasella, J., Alves, L. M., Soares, W. R., \& Rodriguez, D. A. (2011). The drought of 2010 in the context of historical droughts in the Amazon region. Geophysical Research Letters, 38(12), n/a. http://dx.doi.org/10.1029/2011GL047436.

McBratney, A. B., \& Webster, R. (1986). Choosing functions for semi-variograms of soil properties and fitting them to sampling estimates. Journal of Soil Science, 37(4), 617-639. http://dx.doi. org/10.1111/j.1365-2389.1986.tb00392.x.

McKee, T. B., Doesken, N. J., \& Kleist, J. (1993, January). The relationship of drought frequency and duration to time scales. In Proceedings of the 8th Conference on Applied Climatology (Vol. 17, No. 22, pp. 179-183). Boston: AMS.

Medeiros, G. C. S., Maia, A. G., \& Medeiros, J. D. F. (2019). Assessment of Two Different Methods in Predicting Hydrological Drought from the Perspective of Water Demand. Water Resources Management, 33(5), 1851-1865. http://dx.doi.org/10.1007/s11269019-02218-7.

Melo, D. C. D., Scanlon, B. R., Zhang, Z., Wendland, E., \& Yin, L. (2016). Reservoir storage and hydrologic responses to droughts in the Paraná River basin, south-eastern Brazil. Hydrology and Earth System Sciences, 20(11), 4673-4688. http://dx.doi.org/10.5194/ hess-20-4673-2016.

Mishra, A. K., \& Singh, V. P. (2010). A review of drought concepts. Journal of Hydrology (Amsterdam), 391(1-2), 202-216. http://dx.doi. org/10.1016/j.jhydrol.2010.07.012.

National Centers for Environmental Information - NOAA. (2020). Global climate report - annual 2019. USA: NOAA. Retrieved from https://www.ncdc.noaa.gov/sotc/global/201913\#gtegt

Nobre, C. A., Marengo, J. A., Seluchi, M. E., Cuartas, L. A., \& Alves, L. M. (2016). Some characteristics and impacts of the drought and water crisis in Southeastern Brazil during 2014 and 2015. Journal of Water Resource and Protection, 8(2), 252-262. http:/ / dx.doi.org/10.4236/jwarp.2016.82022.

Okpara, J. N., Afiesimama, E. A., Anuforom, A. C., Owino, A., \& Ogunjobi, K. O. (2017). The applicability of Standardized Precipitation Index: drought characterization for early warning system and weather index insurance in West Africa. Natural Hazards, 89(2), 555-583. http://dx.doi.org/10.1007/s11069-017-2980-6.

Pedro-Monzonís, M., Solera, A., Ferrer, J., Estrela, T., \& ParedesArquiola, J. (2015). A review of water scarcity and drought indexes in water resources planning and management. Journal of Hydrology (Amsterdam), 527, 482-493. http://dx.doi.org/10.1016/j. jhydrol.2015.05.003.

Pereira, V. R., Blain, G. C., Avila, A. M. H. D., Pires, R. C. D. M., \& Pinto, H. S. (2018). Impacts of climate change on drought: changes to drier conditions at the beginning of the crop growing season in southern Brazil. Bragantia, 77(1), 201-211. http://dx.doi. org/10.1590/1678-4499.2017007. 
Potter, C., Klooster, S., Hiatt, C., Genovese, V., \& Castilla-Rubio, J. C. (2011). Changes in the carbon cycle of Amazon ecosystems during the 2010 drought. Environmental Research Letters, 6(3), 034024. http://dx.doi.org/10.1088/1748-9326/6/3/034024.

Reichstein, M., Ciais, P., Papale, D., Valentini, R., Running, S., Viovy, N., Cramer, W., Granier, A., Ogée, J., Allard, V., Aubinet, M., Bernhofer, C., Buchmann, N., Carrara, A., Grünwald, T., Heimann, M., Heinesch, B., Knohl, A., Kutsch, W., Loustau, D., Manca, G., Matteucci, G., Miglietta, F., Ourcival, J. M., Pilegaard, K., Pumpanen, J., Rambal, S., Schaphoff, S., Seufert, G., Soussana, J.-F., Sanz, M.-J., Vesala, T., \& Zhao, M. (2007). Reduction of ecosystem productivity and respiration during the European summer 2003 climate anomaly: a joint flux tower, remote sensing and modelling analysis. Global Change Biology, 13(3), 634-651. http:// dx.doi.org/10.1111/j.1365-2486.2006.01224.x.

Santos, C. A. G., Brasil Neto, R. M., Passos, J. S. A., \& Silva, R. M. (2017). Drought assessment using a TRMM-derived standardized precipitation index for the upper São Francisco River basin, Brazil. Environmental Monitoring and Assessment, 189(6), 250. PMid:28470481. http://dx.doi.org/10.1007/s10661-017-5948-9.

Sobral, B. S., Oliveira-Júnior, J. F., de Gois, G., \& Pereira-Júnior, E. R. (2018). Spatial variability of SPI and RDIst drought indices applied to intense episodes of drought occurred in Rio de Janeiro State, Brazil. International Journal of Climatology, 38(10), 3896-3916. http://dx.doi.org/10.1002/joc.5542.

van Vliet, M. T., Sheffield, J., Wiberg, D., \& Wood, E. F. (2016). Impacts of recent drought and warm years on water resources and electricity supply worldwide. Environmental Research Letters, 11(12), 124021. http://dx.doi.org/10.1088/1748-9326/11/12/124021.

Vicente-Serrano, S. M., Beguería, S., \& Camarero, J. J. (2017). Drought severity in a changing climate. In S. Eslamian \& F. A. Eslamian. Handbook of drought and water scarcity (pp. 279-303). CRC Press. http://dx.doi.org/10.1201/9781315404219-16.

Vicente-Serrano, S. M., Beguería, S., Lorenzo-Lacruz, J., Camarero, J. J., López-Moreno, J. I., Azorin-Molina, C., Revuelto, J., MoránTejeda, E., \& Sanchez-Lorenzo, A. (2012a). Performance of drought indices for ecological, agricultural, and hydrological applications. Earth Interactions, 16(10), 1-27. http://dx.doi. org/10.1175/2012EI000434.1.

Vicente-Serrano, S. M., López-Moreno, J. I., Beguería, S., LorenzoLacruz, J., Azorin-Molina, C., \& Morán-Tejeda, E. (2012b). Accurate computation of a streamflow drought index. Journal of Hydrologic Engineering, 17(2), 318-332. http://dx.doi.org/10.1061/(ASCE) HE.1943-5584.0000433.
Wilhite, D. A. (Ed.). (2016). Droughts: a global assesment. London: Routledge. http://dx.doi.org/10.4324/9781315830896.

Wilhite, D. A., \& Glantz, M. H. (1985). Understanding: the drought phenomenon: the role of definitions. Water International, 10(3), 111-120. http://dx.doi.org/10.1080/02508068508686328.

Wilhite, D. A., Svoboda, M. D., \& Hayes, M. J. (2007). Understanding the complex impacts of drought: A key to enhancing drought mitigation and preparedness. Water Resources Management, 21(5), 763-774. http://dx.doi.org/10.1007/s11269-006-9076-5.

Woli, P., Jones, J. W., Ingram, K. T., \& Fraisse, C. W. (2012). Agricultural reference index for drought (ARID). Agronomy Journal, 104(2), 287-300. http://dx.doi.org/10.2134/agronj2011.0286.

World Meteorological Organization (2012). Standardized precipitation index user guide. Geneva: World Meteorological Organization.

World Meteorological Organization - WMO, \& and Global Water Partnership - GWP (2016). Handbook of drought indicators and indices. In M. Svoboda \& B. A. Fuchs. Integrated drought management tools and guidelines (Integrated Drought Management Programme (IDMP), No. 2). Geneva: WMO.

Yevjevich, V. M. (1967). Objective approach to definitions and investigations of continental bydrologic droughts (Hydrology papers, No. 23). USA: Colorado State University.

Zarch, M. A. A., Sivakumar, B., \& Sharma, A. (2015). Droughts in a warming climate: a global assessment of Standardized Precipitation Index (SPI) and Reconnaissance Drought Index (RDI). Journal of Hydrology (Amsterdam), 526, 183-195. http://dx.doi.org/10.1016/j. jhydrol.2014.09.071.

\section{Authors contributions}

Elaisa Teixeira de Jesus: Calculation and spatialization of the index, besides helping in the writing of the article.

Jhones da Silva Amorim: Helped write the article and make the maps.

Rubens Junqueira: Helped write the article and make the maps.

Marcelo Ribeiro Viola: Orientation of activities and review of the article.

Carlos Rogério de Mello: Revision of the final article and suggestions for improvements. 